\title{
Blended Learning as The New Innovation in Physical Education Class
}

\author{
Tandiyo Rahayu ${ }^{1}$, Mohammad Arif $\mathrm{Ali}^{2}$, Katrin Koenen ${ }^{3}$, Andrea Blume ${ }^{4}$, \\ Gustiana Mega Anggita ${ }^{5}$, Billy Castyana ${ }^{6}$, Hermawan Pamot Raharjo $^{7}$ \\ \{tandiyorahayu@mail.unnes.ac.id ${ }^{1}$, hiarifalikhan@mail.unnes.ac.id ${ }^{2}$, kkoenen@icsspe.org $\left.{ }^{3}\right\}$ \\ Universitas Negeri Semarang, Semarang, Indonesia ${ }^{12}$ \\ Senate Department for the Interior and Sport, Berlin, Germany ${ }^{3}$
}

\begin{abstract}
Blended learning is a combined teaching method between conventional and modern technology-based. This study aim to investigate how is the response of students and teachers to the use of blended learning in physical education class. Three different blended learning designs in order to see which the best design for what physical education material, then each design was applied in lesson plans. Total participant in this study is 681 people. In-depth interview to physical education teachers and high school students in Semarang city was performed to collect the data. Regardless the design of blended learning, it takes together blended learning is applicable for physical education learning process as seen in the data that $89 \%$ of participant had agree and only $11 \%$ disagree. Blended learning has accepted very well both by students and PE teachers. Blended learning is acceptable in order to improve the quality of physical education learning process.
\end{abstract}

Keywords: blended learning; physical education; new normal.

\section{Introduction}

Technology development, which has continued to develop in recent years, requires all parties to always update knowledge in any areas, including teaching methods in schools. This update aims to make students benefit maximally from the lessons provided, and to improve the quality of learning as a whole [1], because the scope of learning is unlimited so that students can learn anywhere [2].

Based on these facts, the combination learning model, which is currently known as blended learning, is considered suitable for improving the quality of learning. Therefore, this study aim to investigate how is the response of students and teachers to the use of blended learning in physical education class. 


\section{Materials and Methods}

Design of Physical Education Lesson Plans, we have developed three different blended learning designs in order to see which the best design for what physical education material, then each design was applied in lesson plans. Blended learning design number one is by combaning instructional modalities (teacher demonstration with or without another instructor) and delivery media (video analysis, gaming and simulation, volunteer. Such as FF SetUp 270; Ncesoft Flip Bookmarker 2.8.1; QuizCreator; Screencast 0 Matic, etc.). Blended learning design number two is by combining instructional methods (recitation or drills and student report such as film or writing can be individual or group). Blended learning design number three is by combining online sources (google, youtube, etc.) and face to face instructions (usage of pre-test and post-test, case studies or problem solving, student oral report can be individual or group). More detail information about blended learning designs, see Table 1 . below.

Table 1. Blended learning designs

\begin{tabular}{|c|c|}
\hline \multicolumn{2}{|c|}{$\begin{array}{l}\text { Blended Learning Design Number ONE } \\
\text { Combining Instructional Modalities or Delivery Media }\end{array}$} \\
\hline Instructional Modalities & Delivery Media \\
\hline $\begin{array}{l}\text { Teacher Demonstration with or without } \\
\text { another instructor }\end{array}$ & $\begin{array}{l}\text { Video Analysis, Gaming and Simulation, } \\
\text { Volunteer. } \\
\text { Example: FF Set-Up 270; Ncesoft Flip } \\
\text { Bookmarker 2.8.1; Quiz-Creator; Screencast O } \\
\text { Matic, etc. }\end{array}$ \\
\hline \multicolumn{2}{|c|}{$\begin{array}{l}\text { Blended Learning Design Number TWO } \\
\text { Combining Instructional Methods }\end{array}$} \\
\hline Instructional Methods \#01 & Instructional Methods $\# 02$ \\
\hline Recitation or Drills & $\begin{array}{l}\text { Student Written Report } \\
\text { (individual or group) }\end{array}$ \\
\hline \multicolumn{2}{|c|}{$\begin{array}{l}\text { Blended Learning Design Number THREE } \\
\text { Combining Online and Face to Face Instructions }\end{array}$} \\
\hline Online & Face to Face Instructions \\
\hline Online Sources like Google, YouTube, etc. & $\begin{array}{l}\text { Usage of Pre-Test and Post-Test, Case Studies or } \\
\text { Problem Solving, Student Oral Report (individual } \\
\text { or group) }\end{array}$ \\
\hline
\end{tabular}

Participants, total participant in this study is 681 people (male students = 283, female students $=398$ ), they came from 9 different schools in Semarang Central Java, with variety ages: 14 years old $=1$ participant, 15 years old $=70$ participants, 16 years old $=411$ participants, 17 years old $=188$ participants, 18 years old $=8$ participants, and $>18$ years old $=3$ participants.

Data collection, in-depth interview to physical education teachers and high school students in Semarang city was performed to collect the data. Addressed 
questions was related to determine the level of IT literacy, their expectations for physical education learning, the availability of facilities in schools.

Data analysis, to find the meaning in data which leads to derived knowledge, whereas eventually, data become useful information to make a decision is the main purpose of data analysis. In order to describe basic features (information) of the data in this study, and to emphasize the dominant variables, percentage analysis was used to interpret our primary data, then it is presented in graphical form, [3].

\section{$3 \quad$ Result and Discussion}

Blended learning is a combined teaching method between conventional and modern technology-based. Blended learning has many advantages, including flexibility in terms of distance to learn and can provide opportunities for students to interact with teachers and other students [4]. In fact, it is able to provide the same learning outcomes even beyond traditional teaching [5], [6], (Fig. 1.). Regardless the design of blended learning, it takes together blended learning is applicable for physical education learning process as seen in the data that $89 \%$ of participant had agree and only $11 \%$ disagree, (Fig. 2.).

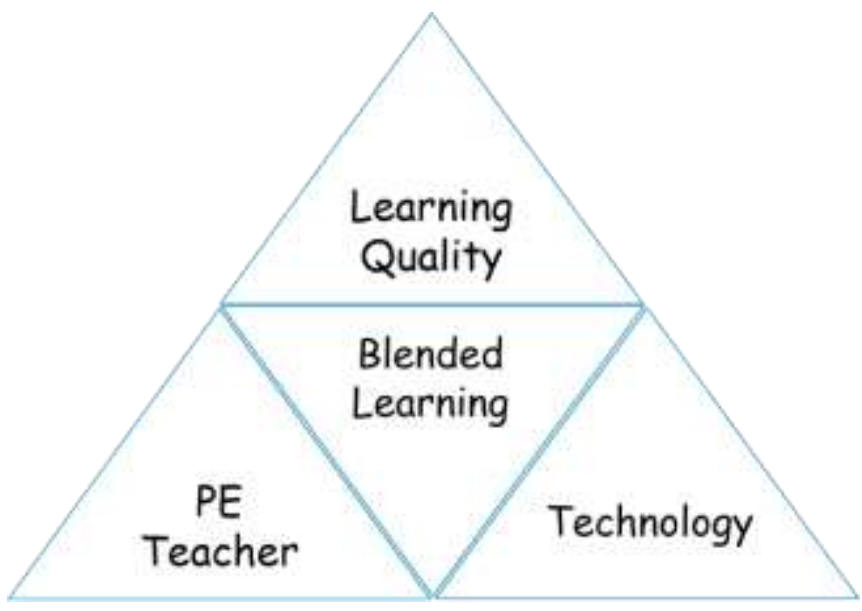

Fig. 1. Concept design of blended learning

Benefits of blended learning are: 1) Besides it offers a public forum, the online resources are always there to help. 2) Every individual receives personalized teaching materials according to their learning needs. 3) Providing good environmental collaborative for participants. 4) It offers better evaluation option of online assessment. 5) It is not only effective in the teaching duration but also reduces travel costs. Meanwhile, shortages of blended learning are the cost of infrastructure and devices, and depending on technology feasibility [7], [8]. 


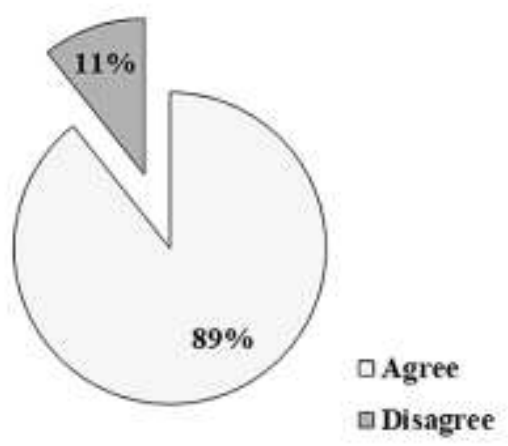

Fig. 2. Blended learning is applicable for physical eduation

How is the response of students and teachers to the use of blended learning in physical education class is answered by four indicators (Ease of using media; Ease of accessing media; Ease of operating media; User satisfaction) we have determined in this research. Blended learning has accepted very well both by students and PE teachers, as it showed in the data (Fig. 3.) $93 \%$ of responses agree with the use of this new approach, and only $7 \%$ disagree. Surprisingly, BLD-01 continuously seems the better, more acceptable (agree: 33\% disagree: $2 \%$ ) followed by BLD-03 (agree: $30 \%$ disagree: $2 \%$ ), and BLD-02 (agree: $30 \%$ disagree: $3 \%$ ).

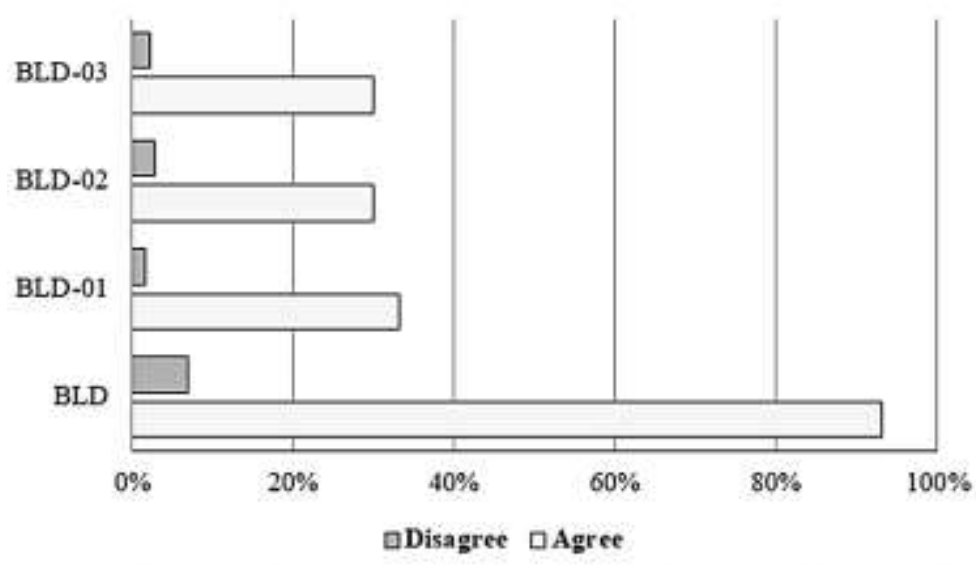

Fig. 3. The response of students and teachers about blended learning for PE

Through blended learning methods students are able to increase their social sense towards peers through this learning method compared to traditional learning and full online learning [9]. This indicates that blended learning is able to combine traditional and online learning well [10] and can be classified ad educational innovation [11]. Moreover, blended learning also affecting students's satisfaction positively as well as 
the tutor's role in problem-based learning [12]. Once students are exposed to tools that encourage their related knowledge on various capabilities, blended learning is able to improve student's productivity. Blended learning allowed educators to be able identify strengths and weakness of their students [13]

Another form of blended learning called Flipped Learning (FL) instruct students individually or in a group to watch online lectures prior to class, then interacting with peers and instructors where this engagement is happening in classroom learning activities [14]. A study conducted by Dankbaar, M. E. W. et al. in 2014, comparing a traditional teaching method and blended learning in training students showing that there was not different in learning results, students' perspective was positive. However, blended learning students showing more confident regarding achievement in learning objectives[15]. Blended learning methods as manifestation of human-to-machine interaction showing capabilities to enhance learning processes [16]. Furthermore, although it is as modern evolution instructional technologies, blended learning still involving some aspects of human thought processes, [17]. Blended learning offers an effective and attractive teaching solution, leading to a significant reduction in costs.

\section{Conclusion}

This study found that blended learning is acceptable in order to improve the quality of physical education learning process in Central Java, Indonesia. This study provides three different designs of blended learning references to modify lesson plans of physical education class according to their (students and teachers) needs.

\section{Acknowledgments}

A research and developments approach for improving physical education teacher professionality. Focus on blended learning to enhance the learning of physical education in Central Java Province - Indonesia. This study was granted by International Council of Sport Science and Physical Education (Biennial Working Proggrame Grant 2019/2020).

\section{References}

[1] C. Williams, "Learning On-line: A review of recent literature in a rapidly expanding field," J. Furth. High. Educ., vol. 26, no. 3, pp. 263-272, Aug. 2002, doi: 10.1080/03098770220149620.

[2] A. R. Sari, "Strategi blended learning untuk peningkatan kemandirian belajar dan kemampuan critical thinking mahasiswa di era digital," J. Pendidik. Akunt. Indones., vol. 11, no. 2, Dec. 2013, doi: 10.21831/jpai.v11i2.1689.

[3] J. Lutabingwa and C. J. Auriacombe, "Data Analysis in Quantitative Research," J. Public Adm., vol. 42, no. 528-548, 2007.

[4] N. Vernadakis, M. Giannousi, V. Derri, M. Michalopoulos, and E. Kioumourtzoglou, "The impact of blended and traditional instruction in 
students' performance," Procedia Technol., vol. 1, pp. 439-443, 2012, doi: 10.1016/j.protcy.2012.02.098.

[5] C. Chen and K. Jones, "Blended learning vs. traditional classroom settings: Assessing effectiveness and student perceptions in an MBA accounting course," J. Educ. Online, vol. 4, no. 1, pp. 1-15, Jul. 2007, doi: 10.9743/JEO.2007.1.3.

[6] B. F. Melton, H. Bland, and J. Chopak-Foss, "Achievement and Satisfaction in Blended Learning versus Traditional General Health Course Designs," Int. J. Scholarsh. Teach. Learn., vol. 3, no. 1, Jan. 2009, doi: 10.20429/ijsotl.2009.030126.

[7] D. Muravlov, "Advantages and Disadvantages of Blended Learning," Racoon Gang, 2018. [Online]. Available: https://raccoongang.com/blog/advantages-anddisadvantages-blended-learning/. [Accessed: 01-Jul-2020].

[8] S. Chen and Y. Lu, "The Negative Effects and Control of Blended Learning in University," in Proceedings of the 2013 the International Conference on Education Technology and Information Systems, 2013, doi: 10.2991/icetis13.2013.7.

[9] A. P. Rovai and H. Jordan, "Blended learning and sense of community: a comparative analysis with traditional and fully online graduate courses," Int. Rev. Res. Open Distrib. Learn., vol. 5, no. 2, Aug. 2004, doi: 10.19173/irrodl.v5i2.192.

[10] I. E. Allen, J. Seaman, and R. Garrett, Blending in: The extent and promise of blended education in the United States. 2007.

[11] D. R. Garrison and N. D. Vaughan, Blended Learning in Higher Education. San Francisco, CA, USA: Jossey-Bass, 2007.

[12] V. Woltering, A. Herrler, K. Spitzer, and C. Spreckelsen, "Blended learning positively affects students' satisfaction and the role of the tutor in the problembased learning process: results of a mixed-method evaluation," Adv. Heal. Sci. Educ., vol. 14, no. 5, pp. 725-738, Dec. 2009, doi: 10.1007/s10459-009-9154-6.

[13] T. I. Oweis, "Effects of Using a Blended Learning Method on Students' Achievement and Motivation to Learn English in Jordan: A Pilot Case Study," Educ. Res. Int., vol. 2018, pp. 1-7, Nov. 2018, doi: 10.1155/2018/7425924.

[14] J. Lee, C. Lim, and H. Kim, "Development of an instructional design model for flipped learning in higher education," Educ. Technol. Res. Dev., vol. 65, no. 2, pp. 427-453, Apr. 2017, doi: 10.1007/s11423-016-9502-1.

[15] M. E. W. Dankbaar, D. J. Storm, I. C. Teeuwen, and S. C. E. Schuit, “A blended design in acute care training: similar learning results, less training costs compared with a traditional format," Perspect. Med. Educ., vol. 3, no. 4, pp. 289-299, Sep. 2014, doi: 10.1007/s40037-014-0109-0.

[16] R. Castro, "Blended learning in higher education: Trends and capabilities," Educ. Inf. Technol., vol. 24, no. 4, pp. 2523-2546, Jul. 2019, doi: 10.1007/s10639-019-09886-3.

[17] C. Dziuban, C. R. Graham, P. D. Moskal, A. Norberg, and N. Sicilia, "Blended learning: the new normal and emerging technologies," Int. J. Educ. Technol. High. Educ., vol. 15, no. 1, p. 3, Dec. 2018, doi: 10.1186/s41239-017-0087-5. 